\title{
THE DEVELOPMENT OF THE DOSAGE FORM WITH L-CARNITINE FOR CHILDREN
}

\author{
O.M.Bezchasnyuk, T.V.Zborovska, S.M.Kovalenko \\ National University of Pharmacy
}

Key words: manufacture of dosage forms for children; L-carnitine; syrup

\begin{abstract}
Treatment of metabolic disorders in children and adults of all ages is the current serious problem. Nowadays much attention is paid to the treatment with drugs based on L-carnitine. The drug for children in the form of a syrup containing L-carnitine has been researched and developed. Drugs with the dosed L-carnitine for children are absent at the modern pharmaceutical market of Ukraine. Suitable dosage forms for children of all ages are liquid forms, including syrups. The drug technology has been developed and tested in the academic research technological laboratory of the National University of Pharmacy for introduction into the pharmaceutical industry of the country. To develop this technology the literature has been analyzed; a number of similar drugs has been identified and their qualitative composition has been studied. The quantitative composition of the drug developed has been determined experimentally. Based on the data of the pharmacological activity of L-carnitine the concentration of the active substance has been selected. The preservatives, modifiers of acidbase properties and flavours have been selected. The sequence of manufacturing operations, which allows creating a quality product, has been determined. A stepwise manufacture of the drug in the flowchart of the technological process has been described. The pharmacotechnological quality characteristics of the medicinal dosage form proposed, namely the drug appearance, $\mathrm{pH}$, relative density and transparency of the resulting solution, have been studied. The results of this work have been included in the pharmaceutical development of the drug.
\end{abstract}

The treatment of metabolic disorders is one of the serious problems in modern medicine. Hundred years of active research of the metabolic role of L-carnitine pathogenetically justifies its use in various pathological conditions both in adults and children, including newborns $[7,8,9]$.

In recent years much attention is paid to the use of L-carnitine in pediatrics. L-carnitine is necessary from the beginning of the child's life. Taking L-carnitine during pregnancy has a positive impact not only on the mother's state, but also on development and the vital activity of the fetus, improving the work of the lungs and the cardiovascular system, as a result, the risk of the sudden infant death syndrome reduces. Newborns differ by deficiency of the energy metabolism. Disorders of the energy metabolism and deficiency of carnitine significantly exacerbate in the case of prematurity, damage of the nervous system, respiratory disorders, cardiovascular disease, anemia and hyperbilirubinemia. L-carnitine penetrates into the organism of an infant with the breast milk or artificial feeding.

The positive action of L-carnitine has been revealed in different spheres of the neuropsychic response due to neurodynamic processes improvement, their activation, switching and regulation; it provides increase of the resistance to physical, intellectual and emotional loads. The most expressed positive effect of the drug is observed with the prolonged use (several months without a break), especially in cases of high exhaustion, psychophysical overload and in gross organic lesions of the nervous system [1, 9-14].
L-carnitine is used in pediatrics in the composition of drugs for adults "Cardonat" and "Trimetabol", in patient information leaflets dosages for children are given, but there are no dosage forms for children. Earlier in the review article we proved the relevance and appropriateness of introduction of a dosage form with L-carnitine for children into medical practice $[3,6]$.

According to the guidelines of the European Medicines Agency EMEA "Formulations of choice for the pediatric population (EMEA/CHMP/PEG/196810/2005)" and ICH E11 "Clinical Investigation of medicinal products in the pediatric population" these patients are usually in a high-risk group:

- premature infants (aged less than 37 weeks);

- newborns (aged 0-28 days);

- younger children (aged from 1 month to 2 years);

- children of the preschool age (aged from 2 to 5 years).

For these patients mainly drugs that are administered orally (syrups, solutions, drops, suspensions) are used with the concentration of the active ingredient, convenient dosing in proportion to the body weight of the child. It is undesirable to use certain preservatives (benzyl alcohol, salts of benzoic acid, lactic acid, etc.), sweeteners (aspartame, xylene, etc.), some flavouring and colouring agents. After the analysis of the current scientific data the composition of the dosage form for children in the form of the syrup based on L-carnitine has been selected.

The syrup of L-carnitine, $10 \%$, belongs to drugs of the metabolic action with the anabolic effect. It shows neuro-, hepato-and cardio protective effects, improves 
Functional purpose of components [5]

\begin{tabular}{|l|l|l|}
\hline \multicolumn{1}{|c|}{$\begin{array}{c}\text { The name } \\
\text { of excipients }\end{array}$} & $\begin{array}{c}\text { Functions } \\
\text { in a dosage form }\end{array}$ & \multicolumn{1}{|c|}{$\begin{array}{c}\text { The influence on technological parameters and characteristics } \\
\text { of the finished product }\end{array}$} \\
\hline Sorbitol & $\begin{array}{l}\text { Preservative, } \\
\text { sweetener (flavour } \\
\text { enhancer) }\end{array}$ & $\begin{array}{l}\text { Introduceed into the composition of a drug as a sweetener and preservative. } \\
\text { The coefficient of sweetness in relation to sucrose is about 0.6; thus, for obtaining } \\
\text { a sweet taste the use of rather high concentrations of sorbitol (15-20\% or } \\
\text { higher) is required. It has a marked osmotic effect, reduces the activity of } \\
\text { water in solutions, and due to it the environment that is unfavourable for } \\
\text { microbial growth creates. The concentration of sorbitol being more than } \\
\text { 30-35\% is sufficient to obtain stable solutions, the concentration of sorbitol } \\
\text { that is less than 10\% does not provide the conservative effect }\end{array}$ \\
\hline $\begin{array}{l}\text { Citric acid } \\
\text { (monohydrate) }\end{array}$ & $\begin{array}{l}\text { Modifier of acid- } \\
\text { base properties, } \\
\text { preservative }\end{array}$ & $\begin{array}{l}\text { Introduced into the formulation as a modifier of acidity and preservative. } \\
\text { Introduction of citric acid shifts pH to the acidic medium, and it increases the } \\
\text { resistance of the active substance to oxidation, improves taste characteristics, } \\
\text { and provides additional preservative effect due to the influence of micro- } \\
\text { organisms on the citric acid cycle. It inhibits malate dehydrogenase, isocitrate } \\
\text { dehydrogenase, succinate dehydrogenase and other enzymes of bacteria }\end{array}$ \\
\hline $\begin{array}{l}\text { Food flavouring } \\
\text { (lemon, orange, mint) }\end{array}$ & Flavour & Introduced into the drug for odour correction \\
\hline Purified water & Solvent & Creates the required concentration of the active ingredient and excipients \\
\hline
\end{tabular}

transmission of nerve impulses in synapses and axons by increasing neurotransmitters and the lipid metabolism, stimulates the cellular immunity, reduces the symptoms of physical and mental fatigue. It is indicated for use primarily in infants and children up to 2-5 years old with the primary and secondary carnitine-deficiency conditions and it is possible to use in older children.

Taking into account the abovementioned we set a goal to develop the technology of a dosage form for children that contains L-carnitine for further introduction into the pharmaceutical production.

\section{Experimental Part}

When developing pediatric drugs the following aspects be must taken into account: the age category of patients treated by the given drug, interaction of the active ingredient with excipients, possible side effects of preservatives, sweeteners, colouring agents and other excipients used in creation of a dosage form for children. The most common dosage forms for children are syrups. They are thick, clear liquids containing one or more active substances dissolved in concentrated aqueous solutions of sucrose or other sugars, and they have a typical taste and odour depending on the composition [2].

To achieve this goal we set the following tasks:

- to determine the qualitative composition of the drug base according to the literary analysis of the existing similar drugs with L-carnitine;

- to select the quantitative content of the drug base;

- to develop the manufacturing technology for the drug;

- to study the pharmacotechnological indicators of the dosage form developed.

L-carnitine is very soluble in water and very hygroscopic. Solubility in water is $2500 \mathrm{mg} / \mathrm{ml}$. Considering the high hygroscopicity the crystalline L-carnitine is used mainly in liquid dosage forms and beverages and practically is not used in solid dosage forms (without coating), BAA (SHP) and dry food products. In neutral and weakly acidic aqueous solutions L-carnitine is sta- ble, but in long storage in the alkaline or oxidized medium it gradually decomposes especially at high temperatures (above $90^{\circ} \mathrm{C}$ ).

L-carnitine is thermostable (at $60^{\circ} \mathrm{C}$ and $90^{\circ} \mathrm{C}$ ) in a dry state and in solutions.

Excipients containing in the syrup of levocarnitine, $10 \%$, used in its development are described in the European Pharmacopoeia and included in "The list of names of excipients containing in the composition of drugs" approved by the Ministry of Public Health of Ukraine from 19.06.2007, No.339 [4].

The syrup of levocarnitine, $10 \%$, contains excipients having the following functions: preservatives, $\mathrm{pH}$ modifiers, sweeteners and flavouring agents (flavours of taste and odour) (Table 1).

Development of the drug - the syrup of levocarnitine, $10 \%$, was conducted using the substance of levocarnitine by NANJING PHARMACEUTICAL FACTORY company from China according to the following stages: - the study of the compositions of the existing analogues of the drug and physicochemical and technological properties of the drug components;

- the experimental testing of the composition of components and its correction for providing the necessary technological and organoleptic properties.

Several pharmaceutical formulations of excipients in different proportions were composed on the basis of analysis of the component composition of the drugs-analogues described in literature, the results of determination of physicochemical and technological properties of the substance, scientific data about the pharmacological activity of L-carnitine.

The concentration of the active ingredient (10\%) was selected on the basis of the available pharmacological data taking into account the ease of dosing for groups of children of diferent age.

Special requirements to drugs for children require minimizing the possible negative effects on the child's 
The preservative action and organoleptic properties of sorbitol in different concentrations

\begin{tabular}{|l|c|c|c|c|}
\hline \multicolumn{1}{|c|}{ Concentration } & $10.0 \%$ & $20.0 \%$ & $30.0 \%$ & $45.0 \%$ \\
\hline Preservative action & $*$ & $*$ & $* *$ & $* * *$ \\
\hline Taste & + & + & ++ & +++ \\
\hline
\end{tabular}

Note. Preservative action: ${ }^{*}$ - weak effect; ${ }^{* *}$ - Moderate effect; ${ }^{* * *}$ - Pronounced effect. Sweet Taste: + - Unexpressed; ++ - Weakly expressed; +++- Expressed

Table 3

The content of a flavoring in the dosage form

\begin{tabular}{|c|c|c|c|c|c|}
\hline Concentration & $0.02 \%$ & $0.03 \%$ & $0.05 \%$ & $0.075 \%$ & $0.10 \%$ \\
\hline Odour & + & ++ & ++ & +++ & ++++ \\
\hline
\end{tabular}

Note: + - Weakly expressed; ++ - Distinct, pleasant; +++ - Strongly expressed; ++++ - Strongly expressed (unpleasant)

organism together with preservation of high organoleptic properties. It is known that such preservatives as benzoic acid and its salts increase the risk of hepatitis $\mathrm{B}$ in infants, benzyl alcohol is toxic and causes allergic reactions in infants and children under 3 years, the concentration of ethanol in the drug for children under 3 years should not exceed $0.5 \%$. The choice of a sweetener is limited by a possible negative effect due to aspartame, some sugars, etc., or unsatisfactory organoleptic and technological properties (glyciram thaumatin, etc.).

Organoleptic properties were evaluated by selecting the concentration of the main taste in relation to taste of the solution taken from a standard with a bitter-astringent taste (Table 2).

Substances, which structure is the closest to the structure of natural substances, have qualitative organoleptic and technological properties, therefore, sorbitol in combination with citric acid, sorbic acid, some sweeteners approved for use in drugs for newborns (sucralose, neohesperydyn, etc.) and flavourings with the odour of mint, lemon and orange approved for use in food products and drugs have been offered as the substances providing organoleptic and preservative properties.

The concentration of sorbitol of $45 \%$ was selected on the basis of available data on the preservative effect of sorbitol at different concentrations taking into account the maximum recommended daily dose of sorbitol.

The concentration of flavours was chosen experimentally. The content of a flavouring (mint, lemon, orange) in the dosage form is given in Table 3.
Table 4

The composition of the medicinal form of levocarnitine syrup, $10 \%$, for children

\begin{tabular}{|l|c|}
\hline \multicolumn{1}{|c|}{ The name of the component } & Amount, $\mathrm{g}$ \\
\hline Levocarnitine & 10.000 \\
\hline Sorbitol & 45.000 \\
\hline Citric acid & 1.000 \\
\hline $\begin{array}{l}\text { Flavouring (mint, lemon, and } \\
\text { orange) }\end{array}$ & 0.037 \\
\hline Purified water & less than $100.000 \mathrm{ml}$ \\
\hline
\end{tabular}

Thus, the optimal amount of a flavouring in the dosage form is $0.03 \%$.

\section{Results and Discussion}

On the basis of the data concerning the pharmacological activity of levocarnitine the concentration of the active substance has been chosen, and experimentally the concentration of excipients in the dosage form of levocarnitine syrup, $10 \%$, for children has been determined.

Based on the results obtained the composition of the drug has been suggested; it is given in Table 4 .

The manufacturing technology of the drug developed (Figure) is acceptable for the enterprises, which produce liquid dosage forms and can be introduced into pharmaceutical manufacture with the purpose of expanding the nomenclature of domestic products.

In the process of our experiment the control of the samples quality was conducted by the pharmacotechno-

Table 5

Pharmacotechnological indicators of quality of levocarnitine syrup, $10 \%$

\begin{tabular}{|l|l|c|}
\hline \multicolumn{1}{|c|}{$\begin{array}{c}\text { The name of the } \\
\text { component }\end{array}$} & \multicolumn{1}{|c|}{ The requirements of the SPhU } & \multicolumn{1}{c|}{ Actual results } \\
\hline $\begin{array}{l}\text { Description } \\
\text { (visually) }\end{array}$ & $\begin{array}{l}\text { A transparent colourless liquid with a sour- } \\
\text { sweet taste and with odour that is typical of the } \\
\text { respective flavour (lemon, mint, orange) }\end{array}$ & $\begin{array}{l}\text { A transparent colourless liquid with a sour- } \\
\text { sweet taste and with odour that is typical of the } \\
\text { respective flavour (lemon, mint, orange) }\end{array}$ \\
\hline $\mathrm{pH}$ & From 4.5 to 5.2 (SPhU 2.2.3.) & 4.81 \\
\hline Relative density & From 1.14 to 1.22 (SPhU 2.2.5. method 1) & 1.19 \\
\hline $\begin{array}{l}\text { Transparency of the } \\
\text { solution }\end{array}$ & $\begin{array}{l}\text { The solution should be transparent } \\
\text { (SPhU 2.2.1.) }\end{array}$ & transparent \\
\hline
\end{tabular}




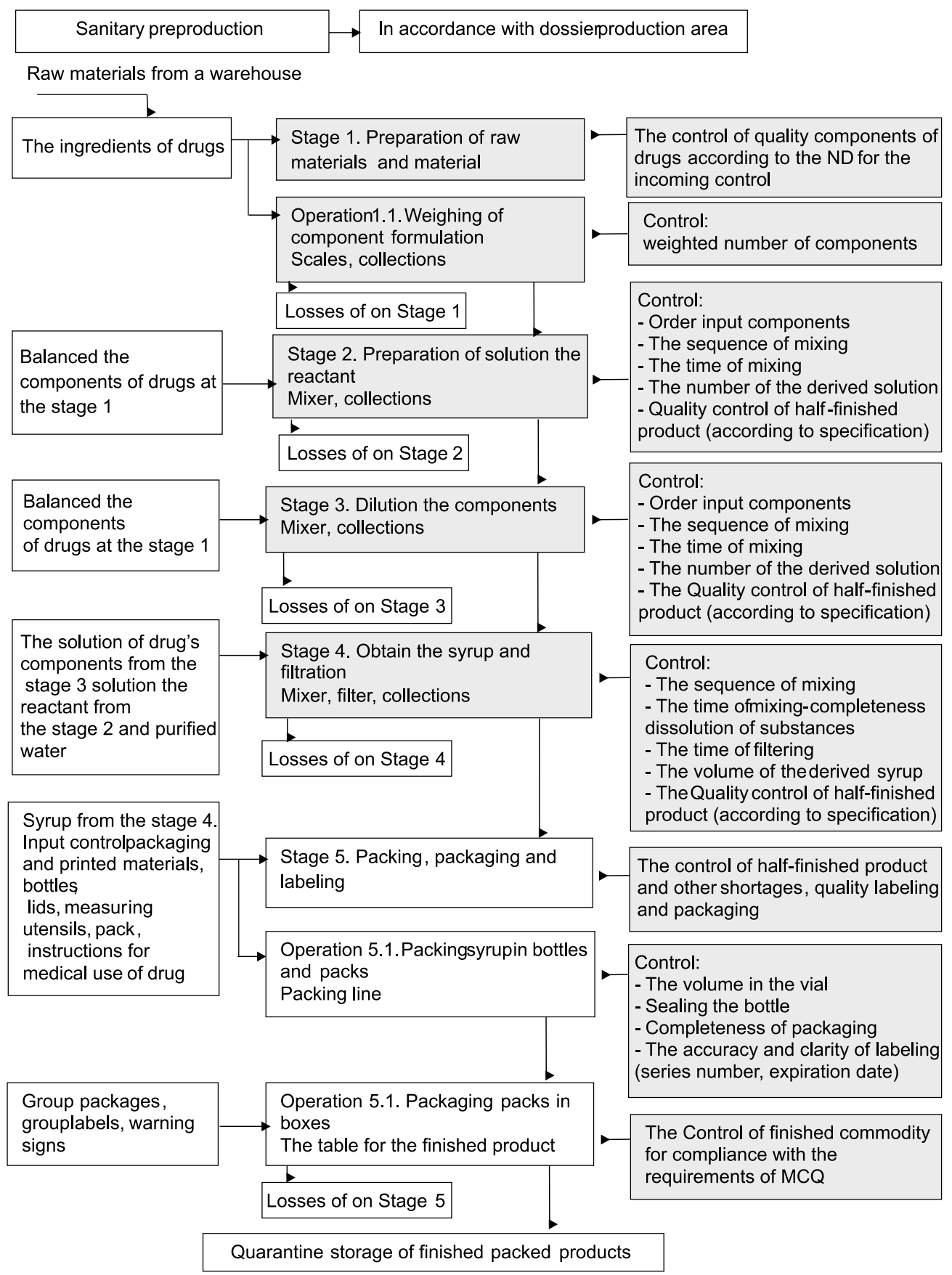

Fig. The technological flowchart of the drug production Note: Critical stages and critical points in the production process are marked in a grey colour.

logical indicators of the drug developed. They are shown in Table 5.

\section{CONCLUSIONS}

1. The literary analysis conducted has proven the expedience of using drugs containing L-carnitine for the treatment of disorders of the energy metabolism in children.

2. The qualitative and quantitative analysis of excipients in the compositions of the available drugs with L-carnitine has been performed. The results of this work have been included in the pharmaceutical development of the drug.

3. In the research technological laboratory at the National University of Pharmacy the technology of a liquid dosage form for children in the form of a syrup has been developed.

4. The pharmacotechnological characteristics of the product developed have been studied. The composition of the drug corresponds to the requirements of the SPhU.

\section{REFERENCES}

1. Брин И.Л. // Вестник педиатр. фармакол. и нутрициол. - 2006. - №2. - С. 32-39.

2. Державна фармакопея України / Державне підриємство «Науково-експертний фармакопейний центр». 1-е вид. - Х.: РІРЕГ, 2001. - 556 c. 
3. Компендіум 2008 -лікарські препарати: в 2-х m. / За ред. В.М.Коваленка, О.П.Вікторова. - К.: Моріон, 2008. - T. 1. -1128 c.; T. 2. -1126 c.

4. Перелік допоміжних речовин, дозволених для застосування у виробництві лікарських засобів, які (лікарські засоби) реєструються в Україні: Наказ МОЗ України від 15.01.2003 p. №8. - К., 2003. - 47 c.

5. Чуєшов В.І., Хохлова Л.М., Ляпунова О.О. та ін. Технологія ліків промислового виробництва: Підруч. / За ред. В.І.Чуєшова. - Х.: Вид-во НФаУ; Золоті сторінки, 2003. - 720 с.

6. Яковлева Л.В. // Укр. журн. клин. и лабораторной медициныл. - 2011. - Т. 6, №2. - С. 17-24.

7. Bohmer T., Rynding A., Solberg H. // Clin. Chim. Acta. - 1974. - №57. - P. 55-61.

8. Feller A.G., Rudman D. // J. of Nutrition. - 1988. - Vol. 118. - P. 541-547.

9. Harmeyer J. // Lohmann Information. - 2002. - №27. - P. 1-8.

10. Meier J. D-Carnitin, harmlos? In Carnitin in der Medizin / R.Gitzelmann, K.Baerlocher \& B. Steinmann (eds.). Stuttgart: Schattauer, 1987. - P. 101-104.

11. Rebouche C.J., Paulson D.J. // Ann. Rev. Nutr. - 1986. - №6. - P. 41-46.

12. Salvioli G., Neri M. // Drugs Exptl. Clin. Res. - 1994. - Vol. 20 (4). - P. 169-176.

13. Sinatra S., Sinatra J. L-Carnitine and the Heart. - 1999. - 64 p.

14. Witte K.K., Clark A.L. // Heart Fail Rev. - 2006. - №11 (1). - P. 65-74.

\section{РОЗРОБКА ДИТЯЧОЇ ЛІКАРСЬКОЇ ФОРМИ 3 L-КАРНІТИНОМ}

\section{О.М.Безчаснюк, Т.В.Зборовська, С.М.Коваленко}

Ключові слова: виробництво дитячих лікарських форм; L-карнітин; сироп

Лікування метаболічних розладів у дітей різного віку та дорослих $є$ сучасною і складною проблемою сьогодення. Велика увага на сьогодні приділяється лікуванню препаратом на основі L-карнітину. Проведені наукові дослідження з розробки лікарського препарату для дітей у фоормі сиропу, що містить L-карнітин. На сучасному фрармацевтичному ринку України відсутні препарати з дитячими дозуваннями L-карнітину. Прийнятними лікарськими фоормами для дітей різного віку є рідкі форми, в тому числі сиропи. Нами було розроблено та апробовано в навчально-науковій технологічній лабораторії лікарських фрорм Національного фрармацевтичного університету технологію виробництва препарату для впровадження в фрармацевтичну промисловість країни. Для розробки технології були проаналізовані літературні джерела та визначено ряд аналогічних препаратів, досліджено їх якісний склад. Експериментальним шляхом встановлено кількісний склад препарату, що розробляється. На підставі даних про фрармакологічну активність L-карнітину підібрана концентрація діючої субстанції. Проведено підбір консервантів, модифікаторів кислотно-лужних властивостей, коригентів запаху та смаку. Також нами було встановлено послідовність технологічних операцій, які дозволяють створити якісний препарат. Постадійне виробниитво препарату викладено в блок-схемі технологічного процесу. Вивчені фрармакотехнологічні показники якості запропонованої лікарської фрорми, а саме зовнішній вигляд препарату, рН, відносна щільність та прозорість отриманого розчину. Результати проведеної роботи будо внесено до фармацевтичної розробки препарату.

\section{РАЗРАБОТКА ДЕТСКОЙ ЛЕКАРСТВЕННОЙ ФОРМЫ C L-КАРНИТИНОМ \\ Е.М.Безчаснюк, Т.В.Зборовская, С.Н.Коваленко}

Ключевые слова: производство детских лекарственных фрорм; L-карнитин; сироп

Лечение метаболических расстройств у детей разного возраста и у взрослых является тяжелой проблемой современности. Большое внимание сегодня уделяется лечению препаратами на основе L-карнитина. Проведены научные исследования по разработке лекарственного препарата для детей в форме сиропа, содержащего L-карнитин. На современном фрармацевтическом рынке Украины отсутствуют препараты с дозировками для детей c L-карнитином. Приемлемыми лекарственными фрормами для детей разного возраста являются жидкие формы, в том числе сиропы. Нами была разработана и апробирована в учебно-научной технологической лаборатории лекарственных фоорм Национального фрармацевтического университета технология производства препарата для внедрения в фрармацевтическую промышленность страны. Для разработки технологии были проанализированы литературные источники и определен ряд аналогичных препаратов, исследован их качественный состав. Экспериментальным путем установлен количественный состав разрабатываемого препарата. На основании данных о фрармакологической активности L-карнитина подобрана концентрация действующей субстанции. Проведен подбор консервантов, модифрикаторов кислотно-щелочных свойств, коригент запаха и вкуса. Также нами была установлена последовательность технологических операций, которые позволяют создать качественный препарат. Постадийное производство препарата изложено в блок-схеме технологического процесса. Изучены фрармакотехнологические показатели качества предложенной лекарственной формы, а именно внешний вид препарата, $\mathrm{pH}$, относительная плотность и прозрачность полученного раствора. Результаты проведенной работы были внесены в фрармацевтическую разработку препарата. 